\title{
INTRAMOLECULAR-PROTON TRANSFER, EXPERIMENTAL AND THEORETICAL CHARACTERIZATION OF 3,3'-DIHYDROXY-4,4'-[4,4'-DIPHENYLMETHANEBIS (NITRILOMETHYLIDYNE)]-BIS-PHENOL
}

\author{
H. Eshtiagh-Hosseini ${ }^{1}$, S.A. Beyramabadi ${ }^{2}$, M. Mirzaei $^{1}$, A. Morsali ${ }^{2}$, M.A. Naseri ${ }^{3}$, \\ H. Chegini ${ }^{2}$, M. Elahi ${ }^{2}$ \\ ${ }^{1}$ Department of Chemistry, Ferdowsi University of Mashhad, Mashhad, Iran \\ ${ }^{2}$ Department of Chemistry, Mashhad branch, Islamic Azad University, Mashhad, Iran \\ E-mail: beiramabadi6285@mshdiau.ac.ir \\ ${ }^{3}$ Department of Chemistry, Faculty of Science, Birjand University, Birjand, Iran
}

\begin{abstract}
A newly synthesized Schiff base 3,3'-dihydroxy-4,4'-[4,4'-diphenylmethanebis(nitrilomethylidyne)]-bis-phenol is characterized experimentally. Also, the geometry optimization for the tautomers, tautomerism and assignment of the IR bands and NMR chemical shifts of the Schiff base were performed using the DFT method. Good consistency between the theoretical and experimental results confirms the validity of the optimized geometry. Geometries of four possible tautomers are fully optimized. None of them has a planar structure, but each of the benzene rings is in a separate plane. In the most stable tautomer $\mathbf{L} 1$, the phenolic protons are engaged in the intramolecular-hydrogen bond with the azomethine nitrogen atoms. Tautomerization of $\mathbf{L 1}$ can occur in two different pathways which are computationally studied using DFT and the Atoms In Molecules (AIM) analysis. Both pathways have the same barrier energy.
\end{abstract}

\section{DOI: $10.15372 / J S C 20150505$}

Keyword s: Schiff base, DFT, tautomerism, assignment, proton transfer, intramolecular hydrogen bond, AIM.

\section{INTRODUCTION}

The syntheses of salen and salophen ligands along with their complexes have received much attention due to their extensive applications, especially in the field of biochemistry and catalysis [ $1-4]$.

Transition metal salen complexes are recognized as powerful homogeneous catalysts in the oxidation reactions. The Schiff base complexes have mainly been used as DNA cleavage catalysts [5-11 ].

In continuation of our previous works on the chemistry of Schiff bases [12-18], herein we report the synthesis, experimental and theoretical investigation of a new Schiff-base (3,3'-dihydroxy4,4'-[4,4'-diphenylmethanebis(nitrilomethylidyne)]-bis-phenol), which is named as $\mathbf{L}$. By comparing the theoretical and experimental results, the validity of the optimized structures has been evaluated.

\section{EXPERIMENTAL}

Materials and methods. All of used chemicals were purchased from Merck Company and used as recieved. Melting points were determined using an electrothermal 9100 melting point apparatus. The IR spectra were recorded on a Buck 500 IR spectrophotometer. Elemental analysis $(\mathrm{C}, \mathrm{H}, \mathrm{N})$ was performed on a Heraeus CHN-O-Rapid elemental analyzer. The ${ }^{1} \mathrm{H}$ and ${ }^{13} \mathrm{C}$ NMR spectra were re- 
corded on a Bruker Drx-500 Avance spectrometer (500.13 MHz), with DMSO as a solvent. Mass spectra were scanned on Shimadzu-GC-Mass-Qp 1100 Ex.

Synthesis of the titled Schiff base $\left(\mathbf{C}_{27} \mathbf{H}_{22} \mathbf{N}_{2} \mathbf{O}_{4}\right)$. A solution of $1.32 \mathrm{~g}(6.66 \mathrm{mmol})$ of 4-(4aminobenzyl)benzenamine and $1.88 \mathrm{~g}(13.61 \mathrm{mmol})$ of dihydroxybenzaldehyde in toluene $(150 \mathrm{ml})$ was refluxed under vigorous stirring with a Dean-Stark for $3 \mathrm{~h}$. The resulting suspension was kept at room temperature prior to being filtered, washed with ethanol $(2 \times 10 \mathrm{ml})$, and dried with diethyl ether $(2 \times 10 \mathrm{ml})$ to afford a red solid. The solid was recrystallized for further purification. (Yield: $58 \%$, m.p. $>250^{\circ} \mathrm{C}$, Anal. Calcd. (\%) for $\mathrm{C}_{20} \mathrm{H}_{20} \mathrm{~N}_{2} \mathrm{O}_{4}$ : C 70.39, H 6.16, N 7.14. Found: C 67.68, H 4.89, $\mathrm{N} 8.28$, the molecular ion peaks, $\left.m / z\left(\mathrm{M}^{+}\right)=438\right)$.

\section{COMPUTATIONAL DETAILS}

All calculations have been performed using density functional theory with the B3LYP functional [19] as implemented in the Gaussian 03 program package [20 ]. The 6-311+G(d,p) basis set was employed.

Firstly, all of the geometries were fully optimized. The optimized geometries were confirmed to have no imaginary frequency of the Hessian, which was used for the additional calculations, including the frequencies, NMR chemical shifts, and AIM calculations. The ${ }^{1} \mathrm{H}$ and ${ }^{13} \mathrm{C}$ NMR chemical shifts of the $\mathbf{L}$ species were predicted with respect to tetramethylsilane (TMS). Here, the GIAO method was used for the prediction of DFT nuclear shieldings [21]. The DFT-predicted vibrational frequencies are usually higher than the experimental ones scaled here by a factor of 0.9614 [22 ].

The AIM topological analyses were carried out in accordance with Bader's approach [23 ] using the AIMall package [24]. The DENSITY = CURRENT option was used to generate the wave function files.

\section{RESULTS AND DISCUSSION}

Geometry optimization. Considering two intramolecular proton transfers, there are four possible tautomers for the titled Schiff base, geometries of which are optimized in both gas and solution phases. The PCM model was used for considering the solvent effects. L1 is the most stable tautomer, where the $\mathrm{H} 1$ and $\mathrm{H} 2$ atoms are bonded to the phenolic $\mathrm{O} 1$ and $\mathrm{O} 2$ atoms. The $\mathbf{L} 1$ tautomeric form is more stable than the $\mathbf{L 2}, \mathbf{L} 3$ and $\mathbf{L} 4$ tautomers by $12.52 \mathrm{~kJ} / \mathrm{mol}^{-1}, 11.70 \mathrm{~kJ} / \mathrm{mol}^{-1}$, and $11.82 \mathrm{~kJ} / \mathrm{mol}^{-1}$ respectively.

In this work, the structural parameters of the L1 Schiff base have been calculated theoretically, and some of them are gathered in Table 1. The obtained results are in agreement with the structural data reported for the similar compounds [ $12-18,25-31]$. The optimized geometry of the investigated Schiff base with its atom labeling is shown in Fig. 1.

The elemental analysis results for the titled Schiff base confirm the proposed formula.

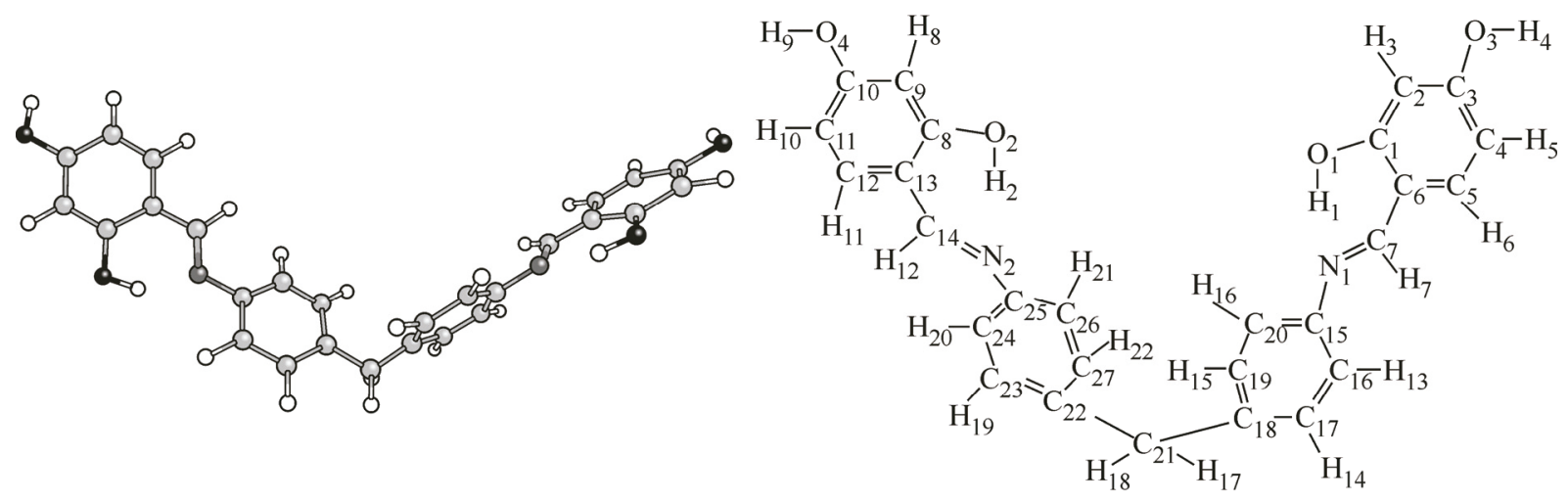

Fig. 1. Structure and B3LYP optimized geometry of L1 together with its labeling 
Selected structural parameters of 3,3'-dihydroxy-4,4'-[4,4'-diphenylmethanebis(nitrilomethylidyne)]-bis-phenol

\begin{tabular}{l|r|l|l|l|r}
\hline \multicolumn{2}{c|}{ Bond length, pm } & \multicolumn{2}{c|}{ Angle, deg. } & \multicolumn{2}{c}{ Dihedral angle, deg. } \\
\hline $\mathrm{O} 1-\mathrm{H} 1$ & 99.5 & $\mathrm{H} 1-\mathrm{O} 1-\mathrm{C} 1$ & 107.5 & $\mathrm{H} 1-\mathrm{O} 1-\mathrm{C} 1-\mathrm{C} 2$ & 179.6 \\
$\mathrm{H} 1-\mathrm{N} 1$ & 173.6 & $\mathrm{~N} 1-\mathrm{H} 1-\mathrm{O} 1$ & 147.8 & $\mathrm{C} 1-\mathrm{C} 2-\mathrm{C} 3-\mathrm{C} 4$ & 0.1 \\
$\mathrm{~N} 1-\mathrm{O} 1$ & 263.2 & & & $\mathrm{C} 2-\mathrm{C} 3-\mathrm{O} 3-\mathrm{H} 4$ & -180.0 \\
$\mathrm{C} 1-\mathrm{O} 1$ & 133.9 & $\mathrm{O} 1-\mathrm{C} 1-\mathrm{C} 2$ & 118.5 & $\mathrm{C} 2-\mathrm{C} 3-\mathrm{C} 4-\mathrm{H} 5$ & 180.0 \\
$\mathrm{C} 1-\mathrm{C} 2$ & 139.5 & $\mathrm{C} 1-\mathrm{C} 2-\mathrm{C} 3$ & 119.9 & $\mathrm{O} 1-\mathrm{C} 1-\mathrm{C} 6-\mathrm{C} 7$ & -0.1 \\
$\mathrm{O} 3-\mathrm{H} 4$ & 96.3 & $\mathrm{C} 2-\mathrm{C} 3-\mathrm{O} 3$ & 117.1 & $\mathrm{C} 1-\mathrm{C} 6-\mathrm{C} 7-\mathrm{N} 1$ & 0.5 \\
$\mathrm{C} 4-\mathrm{H} 5$ & 108.5 & $\mathrm{O} 1-\mathrm{C} 1-\mathrm{C} 6$ & 121.4 & $\mathrm{C} 6-\mathrm{C} 7-\mathrm{N} 1-\mathrm{C} 15$ & -177.1 \\
$\mathrm{C} 6-\mathrm{C} 7$ & 144.4 & $\mathrm{C} 1-\mathrm{C} 6-\mathrm{C} 7$ & 121.6 & $\mathrm{C} 7-\mathrm{N} 1-\mathrm{C} 15-\mathrm{C} 16$ & -145.7 \\
$\mathrm{C} 7-\mathrm{H} 7$ & 109.6 & $\mathrm{C} 6-\mathrm{C} 7-\mathrm{N} 1$ & 122.5 & $\mathrm{C} 15-\mathrm{C} 16-\mathrm{C} 18-\mathrm{C} 19$ & 1.2 \\
$\mathrm{C} 7-\mathrm{N} 1$ & 129.0 & $\mathrm{C} 7-\mathrm{N} 1-\mathrm{C} 15$ & 121.2 & $\mathrm{C} 16-\mathrm{C} 17-\mathrm{C} 18-\mathrm{C} 21$ & 178.2 \\
$\mathrm{~N} 1-\mathrm{C} 15$ & 140.7 & $\mathrm{~N} 1-\mathrm{C} 15-\mathrm{C} 16$ & 118.2 & $\mathrm{C} 17-\mathrm{C} 18-\mathrm{C} 21-\mathrm{C} 22$ & 57.8 \\
$\mathrm{C} 15-\mathrm{C} 16$ & 140.3 & $\mathrm{C} 15-\mathrm{C} 16-\mathrm{C} 17$ & 120.6 & $\mathrm{C} 1-\mathrm{O} 1-\mathrm{O} 2-\mathrm{C} 8$ & -57.1 \\
$\mathrm{C} 18-\mathrm{C} 21$ & 151.8 & $\mathrm{C} 18-\mathrm{C} 21-\mathrm{C} 22$ & 114.8 & $\mathrm{C} 4-\mathrm{C} 1-\mathrm{C} 8-\mathrm{C} 11$ & -55.1 \\
$\mathrm{~N} 1-\mathrm{N} 2$ & 976.6 & $\mathrm{C} 3-\mathrm{O} 3-\mathrm{H} 4$ & 109.9 & $\mathrm{C} 16-\mathrm{C} 19-\mathrm{C} 27-\mathrm{C} 24$ & 162.8 \\
$\mathrm{O} 1-\mathrm{O} 2$ & 1445.2 & & & $\mathrm{C} 7-\mathrm{N} 1-\mathrm{N} 2-\mathrm{C} 14$ & -52.8 \\
$\mathrm{O} 1-\mathrm{N} 1$ & 259.9 & & & $\mathrm{C} 2-\mathrm{C} 1-\mathrm{C} 9-\mathrm{C} 8$ & 126.3 \\
& & & & $\mathrm{C} 1-\mathrm{C} 5-\mathrm{C} 16-\mathrm{C} 20$ & 37.3
\end{tabular}

In the optimized geometry of $\mathbf{L} \mathbf{1}$, the $\mathrm{C}=\mathrm{C}$ bond lengths $(138.2-142.5 \mathrm{pm})$ of the benzene rings are in the expected range. The benzene rings are essentially planar, but each of them lies in a separate plane which make a dihedral angle of approximately $45^{\circ}$ to each other. For example, the $\mathrm{C} 4-\mathrm{C} 3-$ C9- C10 dihedral angle is $-45.1^{\circ}$.

The resorcinol $\mathrm{OH}$ groups are in the same plane with the benzene ring (Table 1). The H1 and $\mathrm{H} 2$ atoms are engaged in intramolecular hydrogen bonds with the azomethine nitrogen atoms (N1 and N2 atoms, respectively), forming two six-membered rings. The calculated N...H hydrogen bond length and $\mathrm{N}-\mathrm{O}$ distance are $173.6 \mathrm{pm}$ and $263.2 \mathrm{pm}$, respectively. The Electron density in the binding region of the $\mathrm{O} 1-\mathrm{H} 1$ and $\mathrm{O} 2-\mathrm{H} 2$ bonds decreases due to these hydrogen bonding interactions. Therefore, the $\mathrm{O} 1-\mathrm{H} 1$ and $\mathrm{O} 2-\mathrm{H} 2$ bonds are longer than the $\mathrm{O} 3-\mathrm{H} 4$ and $\mathrm{O} 4-\mathrm{H} 9$ bonds (by $3.2 \mathrm{pm}$ ) not engaged in the intramolecular H-bonds.

In the diamine-bridge region, two benzene rings are at a dihedral angle of $60^{\circ}$ to each other. The calculated $\mathrm{C} 16-\mathrm{C} 20-\mathrm{C} 27-\mathrm{C} 23, \mathrm{C} 16-\mathrm{C} 17-\mathrm{C} 22-\mathrm{C} 25$ dihedral angles are -59.0 and $-67.0^{\circ}$, respectively.

Both $\mathrm{C} 15-\mathrm{N} 1$ and $\mathrm{C} 25-\mathrm{N} 2$ bond lengths are of appropriate size for the single $\mathrm{C}-\mathrm{N}$ bond, while both azomethine $\mathrm{C} 7-\mathrm{N} 1$ and $\mathrm{C} 14-\mathrm{N} 2$ bonds correspond to the double $\mathrm{C}=\mathrm{N}$ bond. The $\mathrm{C} 7=\mathrm{N} 1$ and $\mathrm{C} 14=\mathrm{N} 2$ bonds are in the same plane with the corresponding benzene rings.

The DFT calculated parameters for the investigated Schiff base are consistent with the previously reported data for the similar salen ligands and complexes [12-18, 25-31].

NMR spectrum. Theoretical and experimental ${ }^{1} \mathrm{H}$ and ${ }^{13} \mathrm{C}$ NMR chemical shifts $(\delta)$ of the $\mathbf{L} \mathbf{1}$ species are listed in Table 2, where the atom positions are numbered as in Fig. 1. The calculated chemical shifts are in agreement with the experimental ones, confirming the suitability of the optimized geometry for the $\mathbf{L}$ Schiff base. The only exceptions are the H4 and H9 hydrogen atoms, where the calculated chemical shifts are significantly lower than the experimental ones. It is notable that the experimental data are from DMSO solutions; while the calculated results correspond to the isolated molecule in the gas phase. Obviously, the solvent molecules interact with the $-\mathrm{OH}$ protons. In addition, the $\mathrm{H} 4$ and $\mathrm{H} 9$ atoms can be engaged in intermolecular hydrogen bonds. 
Experimental and DFT computed ${ }^{1} \mathrm{H}$ and ${ }^{13} \mathrm{C}$ NMR chemical shifts of 3,3'-dihydroxy-4,4'-[4,4'-diphenylmethanebis(nitrilomethylidyne)]-bis-phenol in a DMSO solution, $\delta(\mathrm{ppm})$

\begin{tabular}{|c|c|c|c|c|c|c|c|c|c|c|c|}
\hline \multicolumn{6}{|c|}{${ }^{1} \mathrm{H}$ NMR } & \multicolumn{6}{|c|}{${ }^{13} \mathrm{C}$ NMR } \\
\hline $\begin{array}{l}\text { Atom } \\
\text { position }\end{array}$ & Exp. & Theor. & $\begin{array}{c}\text { Atom } \\
\text { position }\end{array}$ & Exp. & Theor. & $\begin{array}{c}\text { Atom } \\
\text { position }\end{array}$ & Exp. & Theor. & $\begin{array}{c}\text { Atom } \\
\text { position }\end{array}$ & Exp. & Theor. \\
\hline H1 & 13.60 & 13.01 & H15 & 7.30 & 7.22 & $\mathrm{C} 1$ & 163.4 & 172.11 & $\mathrm{C} 17$ & 134.7 & 134.98 \\
\hline $\mathrm{H} 2$ & 13.60 & 13.01 & H19 & 7.30 & 7.22 & $\mathrm{C} 8$ & 163.4 & 171.91 & $\mathrm{C} 27$ & 134.7 & 134.06 \\
\hline H4 & 10.24 & 3.94 & $\mathrm{H} 22$ & 7.30 & 7.22 & $\mathrm{C} 10$ & 162.7 & 167.48 & $\mathrm{C} 20$ & 130.0 & 131.29 \\
\hline H9 & 10.24 & 3.94 & H16 & 7.30 & 7.06 & C3 & 162.7 & 167.37 & $\mathrm{C} 26$ & 130.0 & 129.44 \\
\hline $\mathrm{H} 7$ & 8.80 & 8.52 & $\mathrm{H} 21$ & 7.30 & 7.06 & $\mathrm{C} 7$ & 162.4 & 164.70 & $\mathrm{C} 24$ & 121.5 & 121.81 \\
\hline H12 & 8.80 & 8.36 & H3 & 6.35 & 6.71 & $\mathrm{C} 14$ & 162.4 & 164.70 & $\mathrm{C} 16$ & 121.5 & 120.08 \\
\hline $\mathrm{H} 20$ & 7.42 & 7.48 & $\mathrm{H} 8$ & 6.35 & 6.66 & $\mathrm{C} 15$ & 146.4 & 155.61 & C6 & 112.4 & 118.80 \\
\hline H13 & 7.42 & 7.38 & H10 & 6.29 & 5.96 & $\mathrm{C} 25$ & 146.4 & 154.82 & $\mathrm{C} 13$ & 112.4 & 118.60 \\
\hline H6 & 7.30 & 7.22 & H5 & 6.29 & 5.91 & C18 & 146.4 & 147.38 & $\mathrm{C} 4$ & 108.2 & 107.61 \\
\hline H11 & 7.30 & 7.22 & H17 & 3.97 & 3.71 & $\mathrm{C} 22$ & 146.4 & 147.38 & $\mathrm{C} 11$ & 108.2 & 107.30 \\
\hline \multirow[t]{4}{*}{ H14 } & 7.30 & 7.22 & H18 & 3.97 & 3.71 & $\mathrm{C} 5$ & 139.8 & 138.32 & $\mathrm{C} 2$ & 102.7 & 106.95 \\
\hline & & & & & & $\mathrm{C} 12$ & 139.8 & 138.09 & C9 & 102.7 & 106.95 \\
\hline & & & & & & C19 & 134.7 & 135.68 & $\mathrm{C} 21$ & 45 & 45.21 \\
\hline & & & & & & $\mathrm{C} 23$ & 134.7 & 135.51 & & & \\
\hline
\end{tabular}

A signal at $13.60 \mathrm{ppm}$ is related to the $\mathrm{H} 1$ and $\mathrm{H} 2$ phenolic protons $(\mathrm{H} 1, \mathrm{H} 2)$. Their engagement in the intramolecular hydrogen bond interaction $(\mathrm{O}-\mathrm{H} \ldots \mathrm{N})$, shifts their signals upfield [ 12-18, 32$]$.

Vibrational spectroscopy. Nowadays, a theoretical assignment of the spectra provides a quantitative framework for the understanding and identification of chemical compounds [ 12-18, 33-35 ]. In addition to the NMR chemical shifts, the vibrational modes were analyzed by comparing the DFT and experimental IR spectra. The obtained DFT results could be useful in the identification of similar compounds.

The assignment of the selected vibrational frequencies of the most stable tautomer of the titiled Schiff base $\mathbf{L} \mathbf{1}$ is gathered in Table 3. The broad bond in the $3600-2000 \mathrm{~cm}^{-1}$ spectral region is attributed to the overlap of the $\mathrm{O}-\mathrm{H}$ and $\mathrm{C}-\mathrm{H}$ stretching vibrations [ $12-18,36,37]$. The deconvolution of this region is given in Table 3. The most intense band is related to the stretching vibrations of the $\mathrm{O} 1-\mathrm{H} 1$ and $\mathrm{O} 2-\mathrm{H} 2$ bonds. These vibrations appear at much lower energies than the correspondding vibrations for the $\mathrm{O} 3-\mathrm{H} 4$ and $\mathrm{O} 4-\mathrm{H} 9$ bonds due to the engagement of $\mathrm{H} 1$ and $\mathrm{H} 2$ in the intramolecular hydrogen bonds.

The very intense band in the $1660-1500 \mathrm{~cm}^{-1}$ region is attributed to the azomethine $\mathrm{C}=\mathrm{N}$ bonds. Also, the $\mathrm{C}-\mathrm{O}$ stretching vibrations result in strong bands $[12-18,36,37]$. These two important bands appear at $1624 \mathrm{~cm}^{-1}$ and $1250 \mathrm{~cm}^{-1}$, respectively.

Electrostatic potential map. In the structure of the titled Schiff base there are two possible sites (1 and 2) for the intramolecular proton transfer (IPT) as N...OH between the phenolic - OH group and the azomethine $\mathrm{N}$ atom. Both 1 and 2 sites seem similar, but the IPT can only occur in site 1, which will be explained below.

The electrostatic potentials $V_{\mathrm{S}}(r)$, of the $\mathbf{L 1}, \mathbf{L 2}, \mathbf{L 3}$, and TSL1- $\mathbf{L} 2$ species are shown in Fig. 2, where the negative and positive potentials are shown in red and blue colors, respectively.

As shown in Fig. 2, there is a region of positive $V_{\mathrm{S}}(r)$ in the most external part of $\mathrm{H} 21$ (the region located in the continuation of $\mathrm{O} 8-\mathrm{H} 21$ ) in the overall structure, but a more negative potential in the $\mathbf{L 1}$ and $\mathbf{L 3}$ area of the structure is very prominent. This shows that going from the $\mathbf{L 1}$ and $\mathbf{L 3}$, IPT occurs through site 1 [38]. The negative $V_{\mathrm{S}}(r)$ is located at the outermost part of N25. The interaction between the negative $V_{\mathrm{S}}(r)$ region of $\mathrm{N} 25$ and the positive $V_{\mathrm{S}}(r)$ region of $\mathrm{H} 45$ is one of the reasons for the intramolecular hydrogen bond formation of $\mathbf{L} 1$. 
Selected experimental and calculated IR vibrational frequencies $\left(\mathrm{cm}^{-1}\right)$ of 3,3'-dihydroxy-4,4'-[4,4'-diphenylmethanebis(nitrilomethylidyne)]-bis-phenol

\begin{tabular}{|c|c|c|}
\hline $\begin{array}{l}\text { Experimental } \\
\text { frequencies }\end{array}$ & $\begin{array}{l}\text { Calculated } \\
\text { frequencies }\end{array}$ & Vibrational assignment \\
\hline $831(\mathrm{~m})$ & $\begin{array}{l}845 \\
953\end{array}$ & $\begin{array}{c}\delta_{\text {op }}(\mathrm{O} 1-\mathrm{H} 1, \mathrm{O} 2-\mathrm{H} 2) \\
\text { Breathing of benzene rings }\end{array}$ \\
\hline $1128(\mathrm{~s})$ & 1147 & $\delta_{\text {ip }}($ aromatic hydrogens $)$ \\
\hline $1170(s)$ & 1176 & $v_{\text {asym }}(\mathrm{C} 18-\mathrm{C} 21-\mathrm{C} 22)$ \\
\hline $1190(s)$ & 1225 & $v(\mathrm{C} 6-\mathrm{C} 7, \mathrm{C} 13-\mathrm{C} 14, \mathrm{C} 15-\mathrm{N} 1, \mathrm{C} 25-\mathrm{N} 2)$ \\
\hline \multirow[t]{2}{*}{$1250(\mathrm{~s})$} & 1289 & 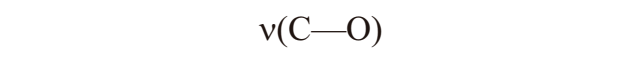 \\
\hline & 1305 & $\delta_{\text {wag }}\left(\mathrm{CH}_{2}\right)$ \\
\hline $1330(\mathrm{~s})$ & 1342 & $\delta_{\mathrm{ip}}(\mathrm{C} 7-\mathrm{H} 7, \mathrm{C} 14-\mathrm{H} 12)$ \\
\hline $1467(\mathrm{~m})$ & 1428 & $v(\mathrm{C} 1-\mathrm{O} 1, \mathrm{C} 8-\mathrm{O} 2)$ \\
\hline $1514(\mathrm{~s}), 1600(\mathrm{vs})$ & 1486,1578 & $v_{\text {sym }}(C=C)$ benzene rings \\
\hline 1624(vs) & 1600 & $v(\mathrm{C} 7=\mathrm{N} 1, \mathrm{C} 14=\mathrm{N} 2)$ \\
\hline \multirow[t]{7}{*}{ 2960(sh), 3423(br) } & 2903 & $v_{\text {sym }}(\mathrm{C} 21-\mathrm{H})$ \\
\hline & 2919 & $v(\mathrm{C} 7-\mathrm{H} 7, \mathrm{C} 14-\mathrm{H} 12)$ \\
\hline & 2934 & $v_{\text {asym }}(\mathrm{C} 21-\mathrm{H})$ \\
\hline & 3051 & $v(\mathrm{O} 1-\mathrm{H} 1, \mathrm{O} 2-\mathrm{H} 2)$ \\
\hline & $3034-3051$ & $v(\mathrm{C}-\mathrm{H})$ aromatic \\
\hline & 3085 & $v(\mathrm{C} 2-\mathrm{H} 3, \mathrm{C} 9-\mathrm{H} 8)$ \\
\hline & 3684 & $v(\mathrm{O} 3-\mathrm{H} 4, \mathrm{O} 4-\mathrm{H} 9)$ \\
\hline
\end{tabular}

A b b r e vi a t i o n s: op — out-of-plane; ip — in-plane; sh — shoulder; w — weak; $\mathrm{m}$ - medium; s — strong; vs — very strong; br — broad.

Topological analysis. The Bader theory is a very suitable tool for analyzing hydrogen bonds. The analysis of the properties of BCPs has often been used as the evaluation of the nature of hydrogen bonds [39-41]. Fig. 2 presents examples of optimized systems, including keto-amine (with the $\mathrm{N}-\mathrm{H}$... O hydrogen bond), its enol-imine tautomeric form (with $\mathrm{O}-\mathrm{H} \ldots \mathrm{N}$ hydrogen bond), and the transition state of the corresponding proton transfer reaction in three pathways.

The parameters derived from the Bader theory, for example, the Laplacian of the electron density $\nabla^{2} \rho$, local electron energy densities of $\mathrm{HC}$ and its components at BCPs are also indicators for the strength of the $\mathrm{H}$ bonds [ 41, 42 ]. The electron energy density (HC), the sum of the kinetic electron energy density (GC), the potential electron energy density (VC), and - GC/VC indicate the interaction type. For a negative value of the Laplacian, the interaction or the bond will doubtlessly be covalent.

If $\nabla^{2} \rho$ and $\mathrm{HC}$ are positive, the interaction is noncovalent. If $\nabla^{2} \rho$ is positive but $\mathrm{HC}$ is negative, and $-\mathrm{GC} / \mathrm{VC}$ is smaller than 1 , then the interaction may be classified as partly covalent in nature [ 38 , 42 ].

The typical topological parameters at $\mathrm{H} \cdots \mathrm{Y} \mathrm{BCP}$ is $0.002-0.04$ a.u. for the electron density and $0.02-0.15$ a.u. for its Laplacian. [ 16, 39, 40 ]. The obtained results for all $\mathrm{O}-\mathrm{H} \ldots \mathrm{N}$ systems analyzed here are as follows: the electron densities at $\mathrm{H} \ldots \mathrm{O}$ BCPs $-\rho \mathrm{H} . . . \mathrm{O}$ are higher than these densities at $\mathrm{H} \ldots \mathrm{N}$ BCPs $-\rho \mathrm{H} \ldots \mathrm{N}$ of $\mathrm{O}-\mathrm{H} \ldots \mathrm{N}$ hydrogen bonds. Additionally, all the $\mathrm{HC}$ values of the BCPs (of $\mathrm{H} \ldots \mathrm{N}$ contacts) are negative, indicating the partly covalent character of these interactions.

The topological parameters, such as $\nabla^{2} \rho_{\mathrm{BCP}}, \nabla^{2} \rho, \mathrm{GC}, \mathrm{VC}$, and $\mathrm{HC}$ at the BCP of N...HO, $\mathrm{O} \ldots \mathrm{HN}$ bonds in two sites of the intramolecular hydrogen bonds are listed in Table 4. 

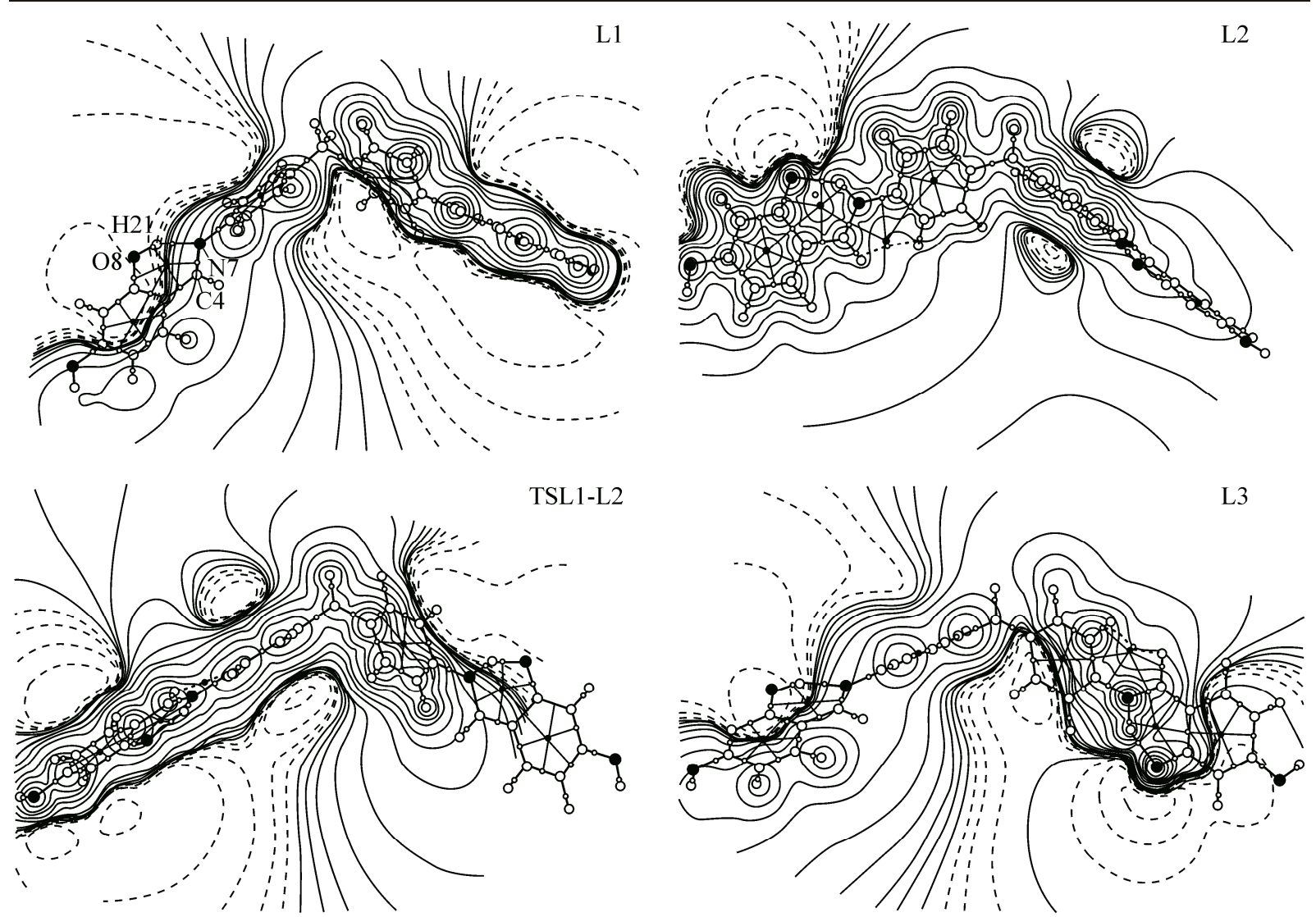

Fig. 2. Electrostatic potential map of the studied species

Table 4

Topological properties at the $\mathrm{BCP}$ of $\mathrm{N}$... HO and $\mathrm{NH}$... $\mathrm{O}$ bonds in the

L1, L3, L4, L2, TsL1-L3, TsL1-L4, TsL1-L2, TsL3-L2, TsL4-L2 species

\begin{tabular}{|c|c|c|c|c|c|c|c|c|}
\hline \multirow{2}{*}{ Species } & \multicolumn{8}{|c|}{ Site1 } \\
\hline & BPL & Bond & $\rho$ & $\nabla 2 \rho$ & GC & $\mathrm{VC}$ & $\mathrm{HC}$ & $-\mathrm{GC} / \mathrm{VC}$ \\
\hline \multirow[t]{2}{*}{ L1 } & 0.972117 & $\mathrm{O} 8-\mathrm{H} 21$ & 0.327138 & -2.25282 & 0.068845 & -0.70089 & -0.63205 & 0.098225 \\
\hline & 1.75772 & $\mathrm{~N} 7-\mathrm{H} 21$ & 0.050205 & 0.111191 & 0.037127 & -0.04646 & -0.00933 & 0.799169 \\
\hline \multirow[t]{2}{*}{ L2 } & 1.706382 & $\mathrm{O} 8-\mathrm{H} 21$ & 0.051589 & 0.146152 & 0.042923 & -0.04931 & -0.00639 & 0.87049 \\
\hline & 1.024362 & N7-H21 & 0.307863 & -1.61499 & 0.048138 & -0.50002 & -0.45188 & 0.096272 \\
\hline \multirow[t]{2}{*}{ L3 } & 0.971993 & $\mathrm{O} 8-\mathrm{H} 21$ & 0.327275 & -2.25399 & 0.068883 & -0.70126 & -0.63238 & 0.098227 \\
\hline & 1.757411 & $\mathrm{~N} 7-\mathrm{H} 21$ & 0.050239 & 0.111324 & 0.037174 & -0.04652 & -0.00934 & 0.799149 \\
\hline \multirow[t]{2}{*}{ L4 } & 1.708572 & $\mathrm{O} 8-\mathrm{H} 21$ & 0.051326 & 0.145851 & 0.042711 & -0.04896 & -0.00625 & 0.872365 \\
\hline & 1.024096 & N7-H21 & 0.308086 & -1.61698 & 0.048075 & -0.5004 & -0.45232 & 0.096074 \\
\hline \multirow[t]{2}{*}{ TSL1-L2 } & 1.261562 & $\mathrm{C} 2-\mathrm{O} 8$ & 0.367507 & -0.38985 & 0.0898 & -1.07976 & -0.98996 & 0.08 \\
\hline & 1.024629 & $\mathrm{~N} 7-\mathrm{H} 21$ & 0.307505 & -1.61211 & 0.068265 & -0.49939 & -0.43113 & 0.136697 \\
\hline \multirow[t]{2}{*}{ TSL1-L3 } & 0.971984 & $\mathrm{O} 8-\mathrm{H} 21$ & 0.32728 & -2.25422 & 0.068849 & -0.70125 & -0.6324 & 0.09818 \\
\hline & 1.75803 & N7-H21 & 0.050163 & 0.111241 & 0.037112 & -0.04641 & -0.0093 & 0.799604 \\
\hline \multirow[t]{2}{*}{ TSL1-L4 } & 1.288617 & $\mathrm{O} 8-\mathrm{H} 21$ & 0.143774 & -0.0319 & 0.089937 & -0.18785 & -0.09791 & 0.478775 \\
\hline & 1.198821 & N7-H21 & 0.194826 & -0.48315 & 0.06832 & -0.25743 & -0.18911 & 0.265397 \\
\hline \multirow[t]{2}{*}{ TSL3-L2 } & 1.292231 & $\mathrm{O} 8-\mathrm{H} 21$ & 0.142483 & -0.02448 & 0.089613 & -0.18535 & -0.09573 & 0.483493 \\
\hline & 1.195815 & $\mathrm{~N} 7-\mathrm{H} 21$ & 0.19614 & -0.49476 & 0.068167 & -0.26003 & -0.19186 & 0.262156 \\
\hline \multirow[t]{2}{*}{ TSL4-L2 } & 1.706761 & $\mathrm{O} 8-\mathrm{H} 21$ & 0.051543 & 0.146101 & 0.042888 & -0.04925 & -0.00636 & 0.870822 \\
\hline & 1.024315 & $\mathrm{~N} 7-\mathrm{H} 21$ & 0.307912 & -1.61528 & 0.04813 & -0.50008 & -0.45195 & 0.096244 \\
\hline
\end{tabular}




\begin{tabular}{|c|c|c|c|c|c|c|c|c|}
\hline \multirow{2}{*}{ Species } & \multicolumn{8}{|c|}{ Site2 } \\
\hline & BPL & Bond & $\rho$ & $\nabla 2 \rho$ & $\mathrm{GC}$ & $\mathrm{VC}$ & $\mathrm{HC}$ & $-\mathrm{GC} / \mathrm{VC}$ \\
\hline \multirow[t]{2}{*}{ L1 } & 0.971926 & $\mathrm{O} 32-\mathrm{H} 39$ & 0.327322 & -2.25519 & 0.068762 & -0.70132 & -0.63256 & 0.098046 \\
\hline & 1.759848 & N35-H39 & 0.049954 & 0.11107 & 0.036948 & -0.04613 & -0.00918 & 0.800971 \\
\hline \multirow[t]{2}{*}{ L2 } & 1.702914 & $\mathrm{O} 32-\mathrm{H} 39$ & 0.051997 & 0.146674 & 0.043275 & -0.04988 & -0.00661 & 0.867547 \\
\hline & 1.024607 & N35-H39 & 0.307751 & -1.61434 & 0.048233 & -0.50005 & -0.45182 & 0.096456 \\
\hline \multirow[t]{2}{*}{ L3 } & 1.707636 & O32-H39 & 0.051439 & 0.146031 & 0.04281 & -0.04911 & -0.0063 & 0.871699 \\
\hline & 1.024212 & N35-H39 & 0.307896 & -1.61554 & 0.048105 & -0.5001 & -0.45199 & 0.096192 \\
\hline \multirow[t]{2}{*}{ L4 } & 0.971646 & $\mathrm{O} 32-\mathrm{H} 39$ & 0.327609 & -2.25819 & 0.068748 & -0.70204 & -0.6333 & 0.097925 \\
\hline & 1.760787 & N35-H39 & 0.049829 & 0.111136 & 0.036887 & -0.04599 & -0.0091 & 0.802048 \\
\hline \multirow[t]{2}{*}{ TSL1-L2 } & 1.29046 & O32-H39 & 0.143119 & -0.028 & 0.043096 & -0.1866 & -0.1435 & 0.230954 \\
\hline & 1.197168 & N35-H39 & 0.19556 & -0.48948 & 0.048181 & -0.2589 & -0.21072 & 0.1861 \\
\hline \multirow[t]{2}{*}{ TSL1-L3 } & 1.289704 & O32-H39 & 0.143373 & -0.02969 & 0.089814 & -0.18705 & -0.09724 & 0.480163 \\
\hline & 1.197992 & N35-H39 & 0.195156 & -0.48616 & 0.068264 & -0.25807 & -0.1898 & 0.26452 \\
\hline \multirow[t]{2}{*}{ TSL1-L4 } & 0.971631 & $\mathrm{O} 32-\mathrm{H} 39$ & 0.32761 & -2.25837 & 0.06873 & -0.70205 & -0.63332 & 0.097899 \\
\hline & 1.761113 & N35-H39 & 0.049793 & 0.111094 & 0.036857 & -0.04594 & -0.00908 & 0.802268 \\
\hline \multirow[t]{2}{*}{ TSL3-L2 } & 1.705088 & $\mathrm{O} 32-\mathrm{H} 39$ & 0.051745 & 0.146386 & 0.043058 & -0.04952 & -0.00646 & 0.869525 \\
\hline & 1.024498 & N35-H39 & 0.307658 & -1.61349 & 0.048178 & -0.49973 & -0.45155 & 0.096408 \\
\hline \multirow[t]{2}{*}{ TSL4-L2 } & 1.291752 & $\mathrm{O} 32-\mathrm{H} 39$ & 0.142652 & -0.02507 & 0.089714 & -0.1857 & -0.09598 & 0.483123 \\
\hline & 1.195838 & N35-H39 & 0.196134 & -0.49435 & 0.068229 & -0.26005 & -0.19182 & 0.262372 \\
\hline
\end{tabular}

The molecular graphs show the existence of a BCP between the $\mathrm{H}(21)$ and $\mathrm{N}(7)$ atoms and the $\mathrm{H}(35)$ and N(39) atoms linked by two bond paths. The topological structure indicates that the intramolecular hydrogen bond exists in $\mathbf{L 1}$. Table 4 shows that at the BCP of the hydrogen bond, $\nabla^{2} \rho$ is positive, while $\mathrm{HC}$ is negative, and the ratio of $\mathrm{GC}$ and $\mathrm{VC}(\mathrm{GC} / \mathrm{VC})$ is between 0.5 and 1 ; all the topological parameters show that the intramolecular hydrogen bond is partly covalent [ 43 ].

In comparison with the other structures, $\rho_{\mathrm{BCP}}$ at the $\mathrm{BCP}$ is greater in $\mathbf{L 1}$, indicating the strongest hydrogen bond for $\mathbf{L 1}$. As compared with the $\mathbf{L 1}$ tautomer, in the $\mathbf{L 2}, \mathbf{L 3}$, and $\mathbf{L} \mathbf{4}$ ones, the absolute values of $\nabla^{2} \rho, \mathrm{GC}, \mathrm{VC}$, and $\mathrm{HC}$ increase while $-\mathrm{GC} / \mathrm{VC}$ decreases, which means that the covalent portion increases in the $\mathbf{L 2}, \mathbf{L 3}$, and $\mathbf{L} 4$ tautomers.

At the first look on the electrostatic potential map, site 1 shows a stronger $\mathrm{H}$-bond than site 2; which is not clearly confirmed by Table 4 data. $\rho_{\mathrm{BCP}}$ at the BCP is expected to change in $\mathbf{L} \mathbf{4}$ towards

T a b l e 5

Dihedral angles $(\AA)$ in site 1 involving $\mathrm{C} 4-\mathrm{C} 15-\mathrm{C} 10-\mathrm{C} 53$ and in site 2 involving $\mathrm{C} 34-\mathrm{C} 43-\mathrm{C} 46-\mathrm{C} 53$ in all molecules and transition states

\begin{tabular}{c|c|c}
\hline Species & C4-C15-C10-C53 (Site 1) & $\mathrm{C} 34-\mathrm{C} 43-\mathrm{C} 46-\mathrm{C} 53$ (Site 2) \\
\hline L1 & -2.3 & 2.3 \\
L2 & -101.4 & 91.2 \\
L3 & -123.5 & 69.4 \\
L4 & -93.2 & 129.0 \\
TSL1-L2 & 36.9 & 88.7 \\
TSL1-L3 & -134.6 & 114.4 \\
TSL1-L4 & -63.1 & 131.5 \\
TSL3-L2 & -111.2 & 78.4 \\
TSL4-L2 & -101.7 & 68.9
\end{tabular}




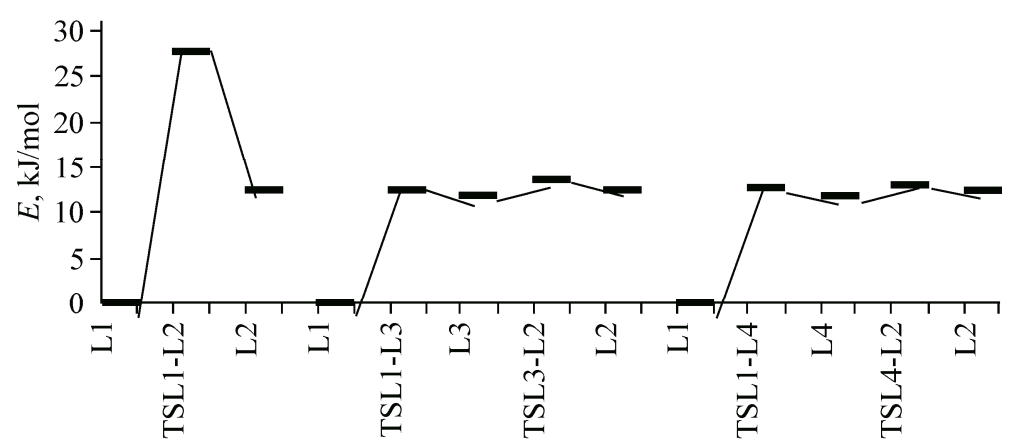

Fig. 3. Relative energy diagram of the $\mathbf{L}$ tautomerization

$\rho_{\mathrm{BCP}}$ at the BCP in L3. Furthermore, the other parameters have been expected to have numerous changes. $\mathbf{L} 4$ has a proton transfer at site 2, but the proton transfer of $\mathbf{L 3}$ locates at site 1. The H...N BCPs $-\rho \mathrm{H} \ldots \mathrm{N}$ of the $\mathrm{O}-\mathrm{H} \ldots \mathrm{N}$ hydrogen bond for $\mathbf{L 3}$ and $\mathbf{L 4}$ are 0.307896 and 0.308086 , respectively. If we focus on the magnitudes of $\nabla^{2} \rho$ and $\mathrm{HC}$, we see that all parameters have a negligible difference in $\mathbf{L} \mathbf{3}$ and $\mathbf{L} \mathbf{4}$ at BCP in the proton transfer bond path.

It is acceptable that two sites have the same opportunity of the intermolecular proton transfer. It is expected because of different dihedral angles of two sites, a distinctive electron density distribution, and different $\mathrm{H}$-bond strengths. However, different H-bonds have not been seen at the two sites, so the dihedral angle has no effect on the proton transfer, which is in good agreement with the energy diagram (Fig. 3).

AIM analysis at RCP. The RCP is a point of the minimum electron density within the ring surface and the maximum on the ring line [44]. The intramolecular hydrogen bond forms a $\mathrm{H}-\mathrm{O}-$ $\mathrm{C}=\mathrm{C}-\mathrm{C}-\mathrm{N}$ ring. Table 6 gives the electron density $\rho_{\mathrm{BCP}}$ at the RCP and $\nabla^{2} \rho$ of this ring. The difference between the RCP and the BCP of the hydrogen bond is also listed in Table 6 .

The extended $d_{\mathrm{RCP} \rightarrow \mathrm{BCP}}$ implies that the hydrogen bond becomes stronger in the $\mathbf{L} \mathbf{1}$ tautomer. This as well means that the properties of RCP $\left(\rho_{\mathrm{RCP}}\right.$ and $\left.\nabla^{2} \rho\right)$ could probably be treated as measures of the intramolecular hydrogen bond strength. The $d_{\mathrm{RCP}} \rightarrow \mathrm{BCP}$ is a good descriptor for explaining the hydrogen bond strength. We see that two sites have the same rule for changing values, but have negligible changes in $\rho_{\mathrm{RCP}}$ that could be affected by the electron deloclization in the ring line, which will be explained below.

Delocalization index. According to Fradera et al. [45], the electron delocalization index (DI) (the average number of electrons delocalized between the bonded A and B atoms) is an evaluation of

T a b l e 6

Topological properties at the $\mathrm{RCP}$, the difference between the $\mathrm{RCP}$ and the $\mathrm{BCP}$ in the studied species

\begin{tabular}{c|l|l|l|l|l|l}
\hline \multirow{2}{*}{ Species } & \multicolumn{3}{|c|}{ Site 1 } & \multicolumn{1}{|c}{ Site 2 } \\
\cline { 2 - 7 } & \multicolumn{1}{|c|}{$\rho$} & \multicolumn{1}{|c|}{$\nabla 2 \rho$} & \multicolumn{1}{|c|}{ dRCP-bcp } & \multicolumn{1}{c|}{$\rho$} & \multicolumn{1}{c}{$\nabla 2 \rho$} & dRCP-bcp \\
\hline L1 & 0.018039 & 0.113238 & 0.820124 & 0.018009 & 0.112974 & 0.819636 \\
L2 & 0.017976 & 0.117117 & 0.838655 & 0.018023 & 0.11754 & 0.838925 \\
L3 & 0.018038 & 0.113271 & 0.820259 & 0.017963 & 0.117011 & 0.838511 \\
L4 & 0.017949 & 0.116871 & 0.83814 & 0.017992 & 0.112867 & 0.819364 \\
TsL1-L2 & 0.018003 & 0.117351 & 0.839279 & 0.02314 & 0.157978 & 0.950622 \\
TsL1-L3 & 0.018032 & 0.113198 & 0.820068 & 0.023143 & 0.158003 & 0.920559 \\
TsL1-L4 & 0.023154 & 0.158056 & 0.950021 & 0.017987 & 0.112825 & 0.819301 \\
TsL3-L2 & 0.021554 & 0.157623 & 0.951166 & 0.017996 & 0.117305 & 0.839035 \\
TsL4-L2 & 0.017971 & 0.117074 & 0.838551 & 0.023136 & 0.157983 & 0.920441
\end{tabular}


Electron delocalization index (average number of electrons delocalized between $\mathrm{A}$ and $\mathrm{B}$ atoms). $q(\mathrm{~A} \mid \mathrm{B})$ Contribution of the bond between $\mathrm{A}$ and $\mathrm{B}$ atoms to $q(\mathrm{~A})$ and $\mathrm{BPL}$ is the bond path length of $\mathrm{A}$ and $\mathrm{B}$ atoms

\begin{tabular}{|c|c|c|c|c|c|c|c|c|}
\hline \multirow{2}{*}{ Species } & \multicolumn{4}{|c|}{ Site 1} & \multicolumn{4}{|c|}{ Site 2} \\
\hline & Bond & $q(\mathrm{~A} \mid \mathrm{B})$ & $\mathrm{DI}(\mathrm{A}, \mathrm{B})$ & BPL & Bond & $q(\mathrm{~A} \mid \mathrm{B})$ & $\mathrm{DI}(\mathrm{A}, \mathrm{B})$ & BPL \\
\hline 1 & 2 & 3 & 4 & 5 & 6 & 7 & 8 & 9 \\
\hline \multirow[t]{6}{*}{ L1 } & $\mathrm{C} 4-\mathrm{N} 7$ & 0.691 & 1.4711 & 1.290822 & C34-N35 & 0.6899 & 1.4713 & 1.153422 \\
\hline & $\mathrm{C} 1-\mathrm{C} 4$ & 0.0332 & 1.1242 & 1.444276 & $\mathrm{C} 30-\mathrm{C} 34$ & 0.0332 & 1.1246 & 1.290468 \\
\hline & $\mathrm{C} 1-\mathrm{C} 2$ & 0.0257 & 1.2009 & 1.425262 & $\mathrm{C} 27-\mathrm{C} 30$ & 0.0263 & 1.2008 & 1.273599 \\
\hline & $\mathrm{C} 2-\mathrm{O} 8$ & 0.6053 & 0.9953 & 1.338791 & $\mathrm{C} 27-\mathrm{O} 32$ & 0.6048 & 0.9956 & 1.196265 \\
\hline & $\mathrm{O} 8-\mathrm{H} 21$ & 0.5304 & 0.4877 & 0.972117 & O32-H39 & 0.5307 & 0.4881 & 0.868495 \\
\hline & $\mathrm{N} 7-\mathrm{H} 21$ & 0.0866 & 0.1295 & 1.75772 & N35-H39 & 0.0862 & 0.1291 & 1.572567 \\
\hline \multirow[t]{6}{*}{ L2 } & $\mathrm{C} 4-\mathrm{N} 7$ & 0.4189 & 1.2137 & 1.331343 & $\mathrm{C} 34-\mathrm{N} 35$ & 0.42 & 1.2135 & 1.189606 \\
\hline & $\mathrm{C} 1-\mathrm{C} 4$ & 0.1438 & 1.3307 & 1.392465 & $\mathrm{C} 30-\mathrm{C} 34$ & 0.1417 & 1.3314 & 1.244299 \\
\hline & $\mathrm{C} 1-\mathrm{C} 2$ & 0.0972 & 1.0561 & 1.473851 & $\mathrm{C} 27-\mathrm{C} 30$ & 0.0955 & 1.0555 & 1.317325 \\
\hline & $\mathrm{C} 2-\mathrm{O} 8$ & 0.9726 & 1.2326 & 1.261269 & $\mathrm{C} 27-\mathrm{O} 32$ & 0.9717 & 1.233 & 1.126997 \\
\hline & $\mathrm{O} 8-\mathrm{H} 21$ & 0.1702 & 0.137 & 1.706382 & $\mathrm{O} 32-\mathrm{H} 39$ & 0.1706 & 0.1376 & 1.521692 \\
\hline & $\mathrm{N} 7-\mathrm{H} 21$ & 0.3353 & 0.5968 & 1.024362 & N35-H39 & 0.3353 & 0.5955 & 0.91557 \\
\hline \multirow[t]{6}{*}{ L3 } & $\mathrm{C} 4-\mathrm{N} 7$ & 0.6934 & 1.4694 & 1.291045 & C34-N35 & 0.4165 & 1.2163 & 1.189082 \\
\hline & $\mathrm{C} 1-\mathrm{C} 4$ & 0.0356 & 1.1258 & 1.443891 & $\mathrm{C} 30-\mathrm{C} 34$ & 0.1476 & 1.3284 & 1.244603 \\
\hline & $\mathrm{C} 1-\mathrm{C} 2$ & 0.0263 & 1.2005 & 1.425453 & $\mathrm{C} 27-\mathrm{C} 30$ & 0.0984 & 1.0567 & 1.316816 \\
\hline & $\mathrm{C} 2-\mathrm{O} 8$ & 0.606 & 0.9955 & 1.338783 & $\mathrm{C} 27-\mathrm{O} 32$ & 0.972 & 1.2327 & 1.127164 \\
\hline & $\mathrm{O} 8-\mathrm{H} 21$ & 0.5295 & 0.4879 & 0.971993 & $\mathrm{O} 32-\mathrm{H} 39$ & 0.1709 & 0.1366 & 1.525911 \\
\hline & $\mathrm{N} 7-\mathrm{H} 21$ & 0.0873 & 0.1294 & 1.757411 & N35-H39 & 0.3348 & 0.5971 & 0.915216 \\
\hline \multirow[t]{6}{*}{ L4 } & $\mathrm{C} 4-\mathrm{N} 7$ & 0.4151 & 1.2156 & 1.330888 & C34-N35 & 0.6931 & 1.4699 & 1.153557 \\
\hline & $\mathrm{C} 1-\mathrm{C} 4$ & 0.1488 & 1.3289 & 1.392789 & $\mathrm{C} 30-\mathrm{C} 34$ & 0.0366 & 1.1256 & 1.290184 \\
\hline & $\mathrm{C} 1-\mathrm{C} 2$ & 0.0992 & 1.0568 & 1.473646 & $\mathrm{C} 27-\mathrm{C} 30$ & 0.0278 & 1.2004 & 1.273685 \\
\hline & $\mathrm{C} 2-\mathrm{O} 8$ & 0.9721 & 1.2338 & 1.261301 & $\mathrm{C} 27-\mathrm{O} 32$ & 0.6051 & 0.9956 & 1.196221 \\
\hline & $\mathrm{O} 8-\mathrm{H} 21$ & 0.171 & 0.1363 & 1.708572 & O32-H39 & 0.53 & 0.4884 & 0.868245 \\
\hline & $\mathrm{N} 7-\mathrm{H} 21$ & 0.3346 & 0.5974 & 1.024096 & N35- H39 & 0.0871 & 0.1286 & 1.573406 \\
\hline \multirow[t]{6}{*}{ TSL1-L2 } & $\mathrm{C} 4-\mathrm{N} 7$ & 0.4185 & 1.2152 & 1.331003 & C34-N35 & 0.4185 & 1.2152 & 1.189359 \\
\hline & $\mathrm{C} 1-\mathrm{C} 4$ & 0.1453 & 1.3295 & 1.392663 & $\mathrm{C} 30-\mathrm{C} 34$ & 0.1453 & 1.3295 & 1.244457 \\
\hline & $\mathrm{C} 1-\mathrm{C} 2$ & 0.0976 & 1.0567 & 1.473722 & $\mathrm{C} 27-\mathrm{C} 30$ & 0.0976 & 1.0567 & 1.31689 \\
\hline & $\mathrm{C} 2-\mathrm{O} 8$ & 0.9716 & 1.2323 & 1.261562 & $\mathrm{C} 27-\mathrm{O} 32$ & 0.9716 & 1.2323 & 1.127308 \\
\hline & $\mathrm{O} 8-\mathrm{H} 21$ & 0.9716 & 1.2323 & 1.261562 & O32-H39 & 0.3315 & 0.2877 & 1.153131 \\
\hline & $\mathrm{N} 7-\mathrm{H} 21$ & 0.3348 & 0.596 & 1.024629 & N35-H39 & 0.2327 & 0.3843 & 1.069766 \\
\hline \multirow[t]{6}{*}{ TSL1-L3 } & $\mathrm{C} 4-\mathrm{N} 7$ & 0.6927 & 1.4701 & 1.290932 & C34-N35 & 0.5372 & 1.3247 & 1.173141 \\
\hline & $\mathrm{C} 1-\mathrm{C} 4$ & 0.0348 & 1.1249 & 1.444052 & $\mathrm{C} 30-\mathrm{C} 34$ & 0.0669 & 1.2329 & 1.263395 \\
\hline & $\mathrm{C} 1-\mathrm{C} 2$ & 0.026 & 1.2007 & 1.425338 & $\mathrm{C} 27-\mathrm{C} 30$ & 0.0349 & 1.1175 & 1.297269 \\
\hline & $\mathrm{C} 2-\mathrm{O} 8$ & 0.6056 & 0.9956 & 1.338802 & $\mathrm{C} 27-\mathrm{O} 32$ & 0.7977 & 1.1296 & 1.155509 \\
\hline & $\mathrm{O} 8-\mathrm{H} 21$ & 0.5299 & 0.488 & 0.971984 & O32- & 0.333 & 0.2881 & 1.152455 \\
\hline & $\mathrm{N} 7-\mathrm{H} 21$ & 0.087 & 0.1294 & 1.75803 & N35-H39 & 0.2313 & 0.3838 & 1.070503 \\
\hline \multirow[t]{6}{*}{ TSL1-L4 } & $\mathrm{C} 4-\mathrm{N} 7$ & 0.5373 & 1.3247 & 1.312859 & C34-N35 & 0.6923 & 1.4705 & 1.153466 \\
\hline & $\mathrm{C} 1-\mathrm{C} 4$ & 0.067 & 1.2322 & 1.41402 & $\mathrm{C} 30-\mathrm{C} 34$ & 0.0356 & 1.1251 & 1.290302 \\
\hline & $\mathrm{C} 1-\mathrm{C} 2$ & 0.0351 & 1.1178 & 1.451688 & $\mathrm{C} 27-\mathrm{C} 30$ & 0.0274 & 1.2006 & 1.273641 \\
\hline & $\mathrm{C} 2-\mathrm{O} 8$ & 0.7973 & 1.1287 & 1.293237 & $\mathrm{C} 27-\mathrm{O} 32$ & 0.6048 & 0.9956 & 1.196229 \\
\hline & $\mathrm{O} 8-\mathrm{H} 21$ & 0.3338 & 0.2886 & 1.288617 & $\mathrm{O} 32-\mathrm{H} 39$ & 0.5303 & 0.4884 & 0.868231 \\
\hline & $\mathrm{N} 7-\mathrm{H} 21$ & 0.2306 & 0.3832 & 1.198821 & N35-H39 & 0.0868 & 0.1286 & 1.573697 \\
\hline
\end{tabular}




\begin{tabular}{|c|c|c|c|c|c|c|c|c|}
\hline 1 & 2 & 3 & 4 & 5 & 6 & 7 & 8 & 9 \\
\hline \multirow[t]{6}{*}{ TSL3-L2 } & $\mathrm{C} 4-\mathrm{N} 7$ & 0.5395 & 1.322 & 1.313404 & C34-N35 & 0.4188 & 1.2148 & 1.189409 \\
\hline & $\mathrm{C} 1-\mathrm{C} 4$ & 0.0648 & 1.2348 & 1.413336 & $\mathrm{C} 30-\mathrm{C} 34$ & 0.1441 & 1.3302 & 1.244349 \\
\hline & $\mathrm{C} 1-\mathrm{C} 2$ & 0.0354 & 1.1168 & 1.452027 & $\mathrm{C} 27-\mathrm{C} 30$ & 0.0969 & 1.0562 & 1.317081 \\
\hline & $\mathrm{C} 2-\mathrm{O} 8$ & 0.8002 & 1.1302 & 1.292914 & $\mathrm{C} 27-\mathrm{O} 32$ & 0.9717 & 1.2329 & 1.127138 \\
\hline & $\mathrm{O} 8-\mathrm{H} 21$ & 0.3306 & 0.2871 & 1.292231 & O32-H39 & 0.1708 & 0.1372 & 1.523635 \\
\hline & $\mathrm{N} 7-\mathrm{H} 21$ & 0.2334 & 0.3854 & 1.195815 & N35-H39 & 0.3353 & 0.5962 & 0.915472 \\
\hline \multirow[t]{6}{*}{ TSL4-L2 } & $\mathrm{C} 4-\mathrm{N} 7$ & 0.4184 & 1.2142 & 1.331201 & C34-N35 & 0.5396 & 1.3225 & 1.173565 \\
\hline & $\mathrm{C} 1-\mathrm{C} 4$ & 0.1452 & 1.33 & 1.392611 & $\mathrm{C} 30-\mathrm{C} 34$ & 0.064 & 1.2351 & 1.262904 \\
\hline & $\mathrm{C} 1-\mathrm{C} 2$ & 0.098 & 1.0564 & 1.473759 & $\mathrm{C} 27-\mathrm{C} 30$ & 0.0344 & 1.1166 & 1.297549 \\
\hline & $\mathrm{C} 2-\mathrm{O} 8$ & 0.9725 & 1.2327 & 1.261332 & $\mathrm{C} 27-\mathrm{O} 32$ & 0.8001 & 1.1301 & 1.155254 \\
\hline & $\mathrm{O} 8-\mathrm{H} 21$ & 0.1705 & 0.1368 & 1.706761 & O32-H39 & 0.3303 & 0.2871 & 1.154285 \\
\hline & $\mathrm{N} 7-\mathrm{H} 21$ & 0.335 & 0.5969 & 1.024315 & N35-H39 & 0.2338 & 0.3851 & 1.068579 \\
\hline
\end{tabular}

the variety of electron pairs shared by two basins; however, they do not declare this function to be a bond order; it is similar to the covalent order defined by Ánglyán et al. [46].

DIs between $(\mathrm{H}-) \mathrm{N}-\mathrm{C}, \mathrm{C}=\mathrm{C}, \mathrm{C}-\mathrm{C}$ and $\mathrm{C}=\mathrm{O}$ or $\mathrm{N}=\mathrm{C}, \mathrm{C}-\mathrm{C}, \mathrm{C}=\mathrm{C}$ and $\mathrm{C}-\mathrm{O}(-\mathrm{H})$ in the chelate ring at both sites are listed in Table 7, which confirms the intramolecular hydrogen bond. Also, Table 7 shows the geometrical parameters of the investigated species. One can notice that the geometries indicate more impressive $\mathrm{O}-\mathrm{H} \ldots \mathrm{N}$ interactions than $\mathrm{N}-\mathrm{H} \ldots \mathrm{O}$ ones. Namely, the H...N distances within $\mathrm{O}-\mathrm{H} . . \mathrm{N}$ bonds are regularly scaled-down by $1.75-1.57 \AA$, while the range of $\mathrm{H}$... distances in the $\mathrm{N}-\mathrm{H}$...O interaction is $1.52-1.70 \AA$. The shortest $\mathrm{H}$... $\mathrm{O}$ and $\mathrm{H}$... N contacts can be found in transition states. It can be supposed that the proton-acceptor distance is the rough evaluation of the hydrogen bonding strength [47].

There are conjugated single-double bonds: $(\mathrm{H}-) \mathrm{N}-\mathrm{C}, \mathrm{C}=\mathrm{C}, \mathrm{C}-\mathrm{C}, \mathrm{C}=\mathrm{O}$ or $\mathrm{N}=\mathrm{C}, \mathrm{C}-\mathrm{C}, \mathrm{C}=\mathrm{C}$, $\mathrm{C}-\mathrm{O}(-\mathrm{H})$ that are more or less equalized due to the $\pi$ electron delocalization (Table 7).

The events described here show that in the case of $\mathrm{N}-\mathrm{H}$... O intramolecular $\mathrm{H}$ bonds, the extra Lewis acid in proximity of the $\mathrm{C}=\mathrm{O}$ proton acceptor causes an increase in Lewis base attraction of the oxygen atom and the weakening of the intramolecular $\mathrm{H}$ bond. All geometrical and topological data (Tables 6 and 7) establish these findings. The electron density increases at the $\mathrm{N}-\mathrm{H} \mathrm{BCP}$; the $\mathrm{H} . . \mathrm{O}$ distance within the $\mathrm{NH} . . . \mathrm{O}$ bridge is elongated and the electron density decreases at the H...O $\mathrm{BCP}$. This leads to an increase in the proton transfer energy barrier for the NH...O tautomeric form, and the contribution of the bond between $\mathrm{A}$ and $\mathrm{B}$ atoms $(q(\mathrm{~A} \mid \mathrm{B}))$ confirms this idea. Thus, at the end of this section, we have come to the same results that were described in other sections: two sites of the IPT (1 and 2) are the same and the dihedral angles have no effect on the barrier energies and percenttage of the tautomers.

\section{CONCLUSIONS}

In this work, 3,3'-dihydroxy-4,4'-[4,4'-diphenylmethanebis(nitrilomethylidyne)]-bis-phenol has newly been synthesized and characterized experimentally by the elemental analysis, NMR and IR spectroscopies. The proposed formula for this Schiff base is in agreement with the experimental results. Four possible tautomers of the Schiff base were investigated computationally using the DFT methods.

The geometries of four possible tautomers of the investigated Schiff base were fully optimized, and L1 was found to be the most stable one. None of the tautomers has a planar structure. The intramolecular hydrogen bonds increase the stability of the investigated tautomers.

In $\mathbf{L 1}$, the $\mathrm{H} 1$ and $\mathrm{H} 2$ phenolic protons are engaged in the intramolecular hydrogen bond (- $\mathrm{O}-$ $\mathrm{H} \ldots \mathrm{N})$, which affects considerably their NMR chemical shifts and the energy of their $\mathrm{O}-\mathrm{H}$ stretching vibration in the IR spectra, too. 
Tautomerism of $\mathbf{L} 1$ can occur in two different pathways (from sites 1 and 2). By a comparison of the electrostatic potential maps of several structures and the topological parameters by the AIMall package, it was finally concluded that the IPT reaction progress from two pathways was equially possible.

The calculated structural parameters are in agreement with the values reported for the similar compounds, confirming the validity of the optimized geometry. On the other hand, the obtained DFT results can be used for the identification of similar compounds.

We gratefully acknowledge financial support of this investigation by Iran National Science Foundation, INSF (Project No. 87020068).

\section{REFERENCES}

1. Sevvel R., Rajagopal S., Srinivasan C., Ismail Alhaji N., Chellamani A. // J. Org. Chem. - 2000. - 65. - P. $3334-3340$

2. Meunier B. // Chem. Rev. - 1992. - 92. - P. $1411-1456$.

3. Ostovic D., Bruice T.C. // Acc. Chem. Res. - 1992. - 25. - P. $314-320$.

4. Canali L., Sherrington D.C. // Chem. Soc. Rev. - 1999. - 28. - P. $85-93$.

5. Bahramian B., Mirkhani V., Moghadam M., Amin A.H. // Appl. Catal., A. - 2006. - 315. - P. 52 - 57.

6. Palucki M., McCormick G.J., Jacobsen E.N. // Tetrahedron Lett. - 1995. - 36. - P. 5457 - 5460.

7. Irie R., Hosoya N., Katsuki T. // Synlett. - 1994. - P. 255 - 256.

8. Linker T. // Angew. Chem., Int. Ed. Engl. - 1997. - 36. - P. 2060 - 2062.

9. Hamada T., Fukuda H., Katsuki T. // Tetrahedron. - 1996. - 52. - P. 515 - 530.

10. Gravert D.J., Griffin J.H. // Inorg. Chem. - 1996. - 35. - P. 4837 - 4847.

11. Routier S.E., Bernier J.L., Warninig M.J., Colson P., Bailly C. // J. Org. Chem. - 1996. - 61. - P. 2326 2331.

12. Eshtiagh-Hosseini H., Housaindokht M.R., Beyramabadi S.A., Beheshti S., Esmaeili A.A., Javan-Khoshkholgh M., Morsali A. // Spectrochim. Acta, Part A. - 2008. - 71. - P. 1341 - 1347.

13. Eshtiagh-Hosseini H., Mirzaei M., Aghabozorg H., Beyramabadi S.A., Eshghi H., Morsali A., Shokrollahi A., Aghaei R. // Spectrochim. Acta, Part A. - 2011. - 78. - P. 1392 - 1396.

14. Eshtiagh-Hosseini H., Housaindokht M.R., Beyramabadi S.A., Mir Tabatabaei S.H., Esmaeili A.A., JavanKhoshkholgh M. // Spectrochim. Acta, Part A. - 2011. - 78. - P. 1046 - 1050.

15. Beyramabadi S.A., Morsali A., Javan-Khoshkholgh M., Esmaeili A.A. // Spectrochim. Acta, Part A. - 2011. - 83. - P. $467-471$.

16. Beyramabadi S.A., Morsali A., Javan-Khoshkholgh M., Esmaeili A.A. // J. Struct. Chem. - 2012. - 53. - P. 460 - 467.

17. Beyramabadi S.A., Morsali A., Shams A.R. // J. Struct. Chem. - 2015. - 56, N 2. - P. $259-265$.

18. Eshtiagh-Hosseini H., Beyramabadi S.A., Morsali A., Mirzaei M., Salimi A.R., Naseri M.A. // J. Struct. Chem. - 2013. - 54. - P. 1063 - 1069.

19. Lee C., Yang W., Parr R.G. // Phys. Rev. B. - 1988. - 37. - P. 785 - 789.

20. Frisch M.J. et al. Gaussian 03, Revision B.03, Gaussian Inc., Pittsburgh, PA, 2003.

21. Ditchfield R. // Mol. Phys. - 1974. - 27. - P. $789-807$.

22. Young D.C. Computational Chemistry: A Practical Guide for Applying Techniques to Real-World Problems, John Wiley \& Sons Inc., 2001.

23. Bader R.F.W. Atoms in Molecules: A Quantum Theory. - Oxford: Clarendon Press, 1994.

24. Biegler-König F., Schönbohm J., Bayles D. // J. Comput. Chem. - 2001. - 22. - P. 545 - 559.

25. Srinivasan K., Michaud P., Kochi J.K. // J. Amer. Chem. Soc. - 1986. - 108. - P. $2309-2320$.

26. Ma C.-B., Chen F., Chen C.-N., Liu Q.-T. // Acta Crystallogr. - 2003. - C59. - P. m516 - m518.

27. Huang D.-G., Zhang X.-F., Zhu H.-P., Chen C.-N., Liu Q.-T. // Acta Crystallogr. - 2001. - E57. - P. m441 $\mathrm{m} 443$.

28. Butcher R.J., Towns W. // Acta Crystallogr. - 2005. - E61. - P. m2618 - m2620.

29. Martinez D., Motevalli M., Watkinson M. // Acta Crystallogr. - 2002. - C58. - P. m258 - m260.

30. Ni Z.-H., Kou H.-Z., Zhang L.-F., Jiang Y.-B., Cui A.-L. // Acta Crystallogr. - 2005. - E61. - P. m796 m798.

31. Gwaram N.S., Khaledi H., Ali H.M. // Acta Crystallogr. - 2010. - E66. - P. m813.

32. Pui A., Policar C., Mahy J.-P. // Inorg. Chim. Acta. - 2007. - 360. - P. $2139-2144$.

33. Takjoo R., Centore R., Hakimi M., Beyramabadi S.A., Morsali A. // Inorg. Chim. Acta. - 2011. - 371. - P. $36-41$ 
34. Leyton P., Paipa C., Berrios A., Zárate A., Castillo M.V., Brandán S.A. // J. Mol. Struct. - 2013. - 1031. - P. $110-118$.

35. Proft F.D., Geerlings P. // Chem. Rev. - 2001. - 101. - P. 1451 - 1464.

36. Sanmartín J., García-Deibe A.M., Fondo M., Navarro D., Bermejo M.R. // Polyhedron. - 2004. - 23. - P. 963 - 967.

37. Ware D.C., Mackie D.S., Brothers P.J., Denny W.A. // Polyhedron. - 1995. - 14. - P. 1641 - 1646.

38. Li X.Y., Wang Y., Zheng S.J., Meng L.P. // Struct. Chem. - 2012. - 23. - P. 1233 - 1240.

39. Bader R. Atoms in Molecules: A Quantum Theory. - Oxford: Clarendon, UK, 1990.

40. Filarowski A., Majerz I. // J. Phys. Chem. A. - 2008. - 112. - P. 3119 - 3126.

41. Espinosa E., Souhassou M., Lachekar H., Lecomte C. // Acta Crystallogr., Sect. B: Struct. Sci. - 1999. - 55. - P. $563-572$.

42. Grabowski S.J. // J. Phys. Chem. A. - 2000. - 104. - P. $5551-5557$.

43. Jenkins S., Morrison I. // Chem. Phys. Lett. - 2000. - 317. - P. 97 - 102.

44. Mariam Y.H., Musin R.N. // J. Phys. Chem. A. - 2008. - 112. - P. $134-145$.

45. Carroll M.T., Bader R.F. // Mol. Phys. - 1988. - 65. - P. $695-722$.

46. Ángyán J.G., Loos M., Mayer I. // J. Phys. Chem. - 1994. - 98. - P. 5244 - 5248.

47. Kolandaivel P., Nirmala V. // J. Mol. Struct. - 2004. - 694. - P. 33 - 38.

48. Gatti C., Saunders V.R., Roetti C. // J. Chem. Phys. - 1994. - 101. - P. $10686-10696$.

49. Grabowski S.J. // J. Mol. Struct.: THEOCHEM. - 2007. - 811. - P. $61-67$. 